\title{
Eastern Cherry Fruit Fly, Rhagoletis cingulata (Loew) (Insecta: Diptera: Tephritidae) ${ }^{1}$
}

H. V. Weems, Jr. ${ }^{2}$

\section{Introduction}

Larvae of two closely related species of fruit flies in central and eastern North America -Rhagoletis cingulata (Loew), commonly called the cherry fruit fly or cherry maggot, and Rhagoletis fausta (Osten Sacken), the black cherry fruit fly -attack cherry and cause wormy fruits. Only $R$. cingulata occurs in Florida, where it attacks wild cherries and is of little economic importance. These two species closely resemble a third pest species, the apple maggot, Rhagoletis pomonella (Walsh); the adults of all three have banded wings. $R$. cingulata breeds in all varieties of cherries including the sweet cherry.

A weevil, the plum curculio, Conotrachelus nenuphar (Herbst) is the most serious pest of cherries and plums, and its larvae may be mistaken for those of the fruit flies. However, plum curculio larvae have heavy chewing mandibles and a bluntly rounded head which readily distinguish them from fruit fly larvae which have sharp-pointed, downward-curved mouth hooks and a sharply pointed head.

\section{Synonyms}

Trypeta cingulata Loew, 1862

\section{Distribution}

Michigan to New Hampshire, southward to Florida, occurring over the entire middle and eastern region of the United States; southeastern and southcentral Canada. Rhagoletis indifferens Curran, once considered a subspecies of $R$. cingulata, occurs in the western United States from Idaho and Washington southward into California. R. fausta, the third species in this complex, occurs across southern Canada southward to New York in the east and to California along the west coast.

\section{Identification}

These flies are a little smaller than a house fly, 4 to $5 \mathrm{~mm}$ long, and generally black with yellow margins on the thorax. The scutellum is white, the tibiae and tarsi are yellowish, and there are transverse and oblique blackish markings on the wings. The cherry fruit fly has four white crossbands on the abdomen, which are not found on the black cherry

1. This document is EENY-203 (originally published as DPI Entomology Circular 116), one of a series of Featured Creatures from the Entomology and Nematology Department, Florida Cooperative Extension Service, Institute of Food and Agricultural Sciences, University of Florida. Published: March 2001. This document is also available on Featured Creatures Website at http://creatures.ifas.ufl.edu. Please visit the EDIS Website at http://edis.ifas.ufl.edu and the Entomology and Nematology Department website at http://entnemdept.ifas.ufl.edu/. 2. H. V. Weems, Jr., Florida Department of Agriculture and Consumer Services, Division of Plant Industry, Gainesville, FL.

The Institute of Food and Agricultural Sciences (IFAS) is an Equal Employment Opportunity - Affirmative Action Employer authorized to provide research, educational information and other services only to individuals and institutions that function without regard to race, creed, color, religion, age, disability, sex, sexual orientation, marital status, national origin, political opinions or affiliations. For information on obtaining other extension publications, contact your county Cooperative Extension Service office. Florida Cooperative Extension Service / Institute of Food and Agricultural Sciences / University of Florida / Larry R. Arrington, Interim Dean 


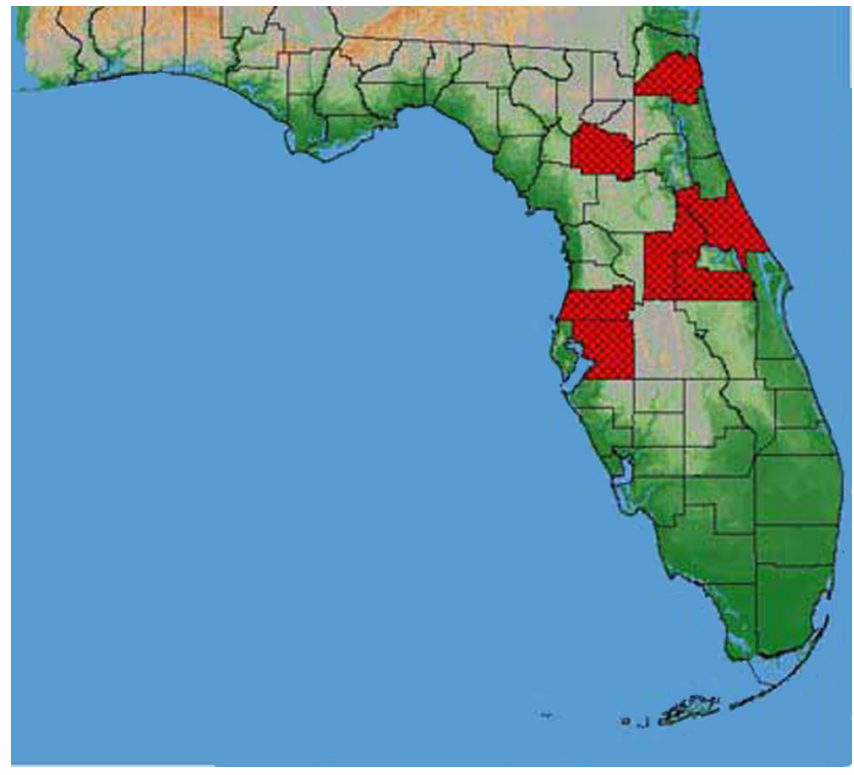

Figure 1. Distribution of the eastern cherry fruit fly, Rhagoletis cingulata (Loew), in Florida. Credits: G. J. Steck and B. D. Sutton, Division of Plant Industry

fruit fly; the blackish bands on the wings of the latter are more intense.

The maggots found in the fruit are yellowish white, up to 1/4 inch long and -- typical of fly larvae -- are pointed at the head end. Key characters for the separation of the larval stage from related species are given by Phillips (1946).

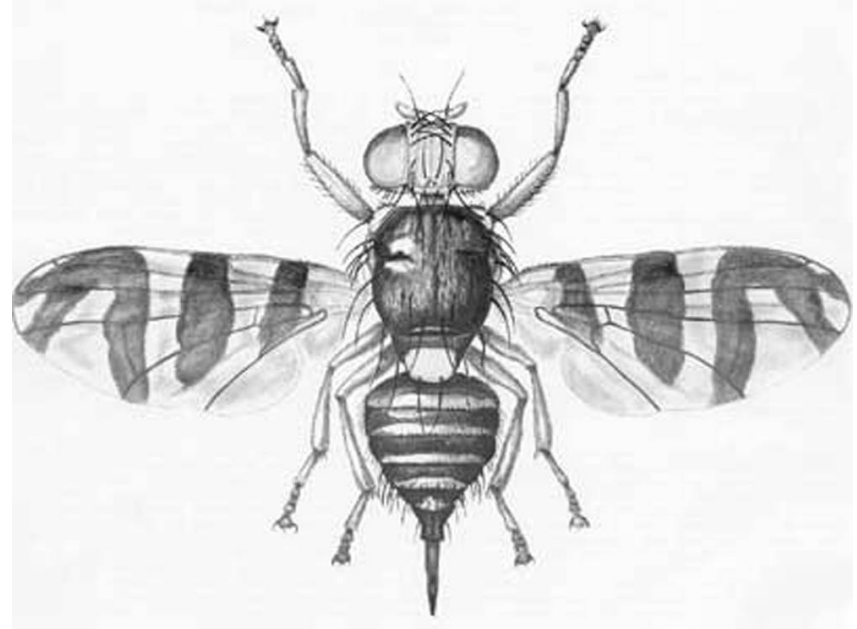

Figure 2. Adult female eastern cherry fruit fly, Rhagoletis cingulata (Loew). Credits: Division of Plant Industry

\section{Life History and Habits}

Adults emerge from the ground during the spring at the time the cherries are about half grown and feed for a few days on moisture and other materials on the surface of the leaves and fruit before laying eggs. This is the vulnerable time for control. Each female may deposit 300 to 400 eggs. Only one larva matures in a fruit, although more than one egg may be deposited in a single fruit. After oviposition the eggs hatch in five to eight days, and the young larvae tunnel directly to the surface of the cherry seed. They pass through three instars at an average of 11 days at $77^{\circ} \mathrm{F}$.

By the time the cherries are ripe the larvae mature, drop to the ground, and burrow into the soil to a depth of one to three inches where they pupate and eventually overwinter. Infested cherries at first do not fall but hang on the tree, and sunken areas may develop on some of them. By harvest time as many as 75 per cent of the cherries may be infested. Many larvae are likely to be in the fruits of early varieties at harvest time, pass undetected, and be distributed around the country in marketing. A few flies emerge in August and September as a second generation, but about 99 per cent require a year to complete a life cycle.

\section{Hosts}

Cultivated cherries (sweet cherry, Prunus avium L.; sour cherry, Prunus cerasus L.; Mahaleb or St. Lucie cherry, Prunus mahaleb L.) and wild cherry (Prunus serotina Ehrh.). R. cingulata has been reared from plum (Prunus spp.), fringe tree (Chionanthus virginica L.), and wild olive (Osmanthus americanus (L.) Gray). R. cingulata attacks both sweet and sour cherries while $R$. fausta primarily attacks the sour cherries. Since both are native species, their original food must have been the wild species of cherry.

\section{Selected References}

Davidson RH, Peairs LM. 1966. Insect Pests of Farm, Garden, and Orchard. John Wiley \& Sons, Inc., New York. 675 p.

Phillips VT. 1946. The biology and identification of trypetid larvae (Diptera: Trypetidae). Memoirs of the American Entomological Society 12: 161.

Garman P, et al. 1956. Plant pest handbook. Connecticut Agricultural Experiment Station Bulletin 600: 1-194. 
Glasgow H. 1933. The host relations of our cherry fruit flies. Journal of Economic Entomology 26: 431-438.

Metcalf CL, Flint WP, Metcalf RL. 1962.

Destructive and Useful Insects, their Habits and Control. McGraw-Hill Book Co., Inc., New York. $1087 \mathrm{p}$.

Quayle HJ. 1941. Insects of citrus and other subtropical fruits. Comstock Publishing Co., Inc., Ithaca, New York. 583 p.

Stone Alan, et al. 1965. A Catalogue of the Diptera of America North of Mexico. USDA Agricultural Handbook No. 276. 1696 p.

White IM, Elson-Harris MM. 1994. Fruit Flies of Economic Significance: Their Identification and Bionomics. CAB International. Oxon, UK. 601 p. 